\title{
Eye Fatigue on Employees of Computer Users at PT. Bank X in Ambon City Maluku Indonesia
}

\author{
Lorna Yulaina Rary $^{1}$, Gracia Victoria Souisa ${ }^{2}$ ), Bellytra Talarima $^{3}$ \\ 1,2*), 3 Fakultas Kesehatan Universitas Kristen Indonesia Maluku
}

\section{ARTICLE INFO}

Article history:

Received February 12, 2019

Revised April 1, 2019

Accepted April 3, 2019

\section{Keyword:}

Pengguna komputer

Kelelahan mata

Karyawan Bank

*) corresponding author

Dosen Program Studi Ilmu Kesehatan Masyarakat, Fakultas Kesehatan,

Universitas Kristen Indonesia Maluku,

Ambon, Jl OT Pattimaipauw, Ambon

Tlp.(0911) 346206

Email: souisagracia@gmail.com

DOI:http://doi.org/10.30604/jika.v4i1.172

\begin{abstract}
A B S T R A C T
Using computers for long periods of time can cause eye fatigue. The ILO, AOA, NIOSH and CVS Statistics data show that eye fatigue is common among computer users. Therefore, this study aims to determine the factors that related to eye fatigue. The research design used observational-analytic with cross-sectional method. The number of samples in this study as many as 25 employees of computer users, used total sampling. Research data obtained by using questionnaires filled by employees to know the length of time, work and eye fatigue sufferers, roll meter to measure the distance of the monitor to the eye and Lux meter to measure the room lighting. Data analysis is done by univariate and bivariate analysis with chi square test. The result of the research shows that the length of working time using computer obtained Pvalue $=0.003$, the monitor distance obtained result Pvalue $=0.245$ and room lighting obtained result Pvalue $=$ 0.042. So it can be concluded that the length of time working using computers and lighting the room related to eye fatigue.
\end{abstract}

This is an open access article under the CC-BY-SA license.

\section{INTRODUCTION}

Eye fatigue, according to Medical Sciences is a symptom caused by excessive effort of the visual system that is in a condition that is not perfect for obtaining visual acuity. Eye fatigue is a disorder that is experienced by the eye because the muscles are forced to work hard, especially when you have to see a close object in a long time. All activities related to coercion of these muscles to work hard, as the other muscles will be able to make the eye experience interference. Interference will appear after several hours of work. Disorders or symptoms that indicate a 
worker experiencing eye fatigue are uncomfortable eyes, hot eyes, sore eyes, fatigue, red eyes, runny eyes, double vision or blurredness, headaches, back pain, back pain and vertigo (Ilyas \& Yulianti, 2017; Shayla Wilson, 2015)

The use of digital tools such as computers for work and social purposes is often done for hours every day (Sheppard \& Wolffsohn, 2018). Eye fatigue often occurs in workers who use computers. The results of Portello's study, Rosenfield, \& Bababekova (2012), reported 10 symptoms of computer use such as eye discomfort, sensitivity to bright lights, tired eyes, eye strain, dry eyes, irritated or burning eyes, difficulty or slowness in refocusing my eyes from one distance to another, blurred vision when looking into the distance, blurred vision while viewing the computer. The use of a computer for a long time will cause impaired vision function and reduced visual acuity. Riskedas data prove that the prevalence of damage to eye vision function and a decrease in visual acuity of less than $6 / 18$ at productive age (15-54 years) is $1.49 \%$ (Ministry of Health, 2013).

The use of computers in the business sector in Indonesia can trigger eye fatigue, especially among computer users. This will directly or indirectly affect the efficiency and productivity of work (Supriadi, 2012). Research conducted by Sya'ban \& Riski, (2014) on employees of computer users in Grapari Telkomsel Kendari proved as many as 24 employees with a percentage of $92.3 \%$ who worked below the level of lighting experienced complaints of eye fatigue while workers who experienced complaints of eye fatigue as a result of the long duration of computer exposure as much as 26 employees with a percentage of $96.3 \%$. The research on the Moon, et al (2014), also shows that there is a relationship between the duration of smartphone use and the risk of dry eye disease $(p=0.027)$. Another study from Moon, et al (2016) in the control group and the dry eye disease group showed that the longer average smartphone usage in the group with the incidence of dry eye disease was longer than the control group. Research by Fadhillah (2013) on computer users in Accounting Group PT Bank X. Jakarta showed 72 computer users with a percentage of $72 \%$ experiencing complaints of eye fatigue. Furthermore, the results of research from Septiansyah, (2014) on computer user workers at PT. Ambassador Astakona Girinda explained that there were 35 computer user workers who experienced eye fatigue in the amount of $70 \%$. Many eye fatigue is experienced by workers because the distance and lighting at the work desk are not in accordance with established standards and are caused by a long duration of computer usage in a day. The results of the study concluded that the onset of eye fatigue was influenced by several factors derived from work device factors (monitor distance, object size on screen, screen display), work environment (room lighting, air temperature), work design (document characteristics, duration work) and individual characteristics (age, refractive disorders, eye rest, history of illness). But when viewed from previous studies, the main reason for the occurrence of eye fatigue is the duration of work that is more specifically for working time using a computer in a day, the distance of the eye that is too close to the monitor, so the eye is forced to work to see a fairly close distance in a long period of time, while the function of the eye itself is actually not specifically for viewing at close range. Eye fatigue is also influenced by lighting in the work environment. Low-intensity lighting can cause eye fatigue, eye strain, and achy complaints around the eyes while the intensity of highlighting can cause glare that interferes with work (Santoso, 2013; Suma'mur, 2013).

PT. Bank $\mathrm{X}$ is one of the banks in Ambon city and has a working area outside the city of Ambon, which in doing work and services, employees are very dependent on the use of computers. Based on preliminary observations, the employees worked for 8 hours with 1 hour rest time every Monday to 
Friday from 08.00-17.00 WIT, but sometimes exceeded working hours or overtime. This can cause eye fatigue. Eye fatigue can reduce visual ability, decrease work productivity, loss of working hours and reduce job satisfaction because workers experience various complaints that cause loss of concentration and decrease the morale of workers (Suma'mur, 2013). In addition, employees at PT Bank X have never been given information about the importance of eye rest when using a computer. This study gave a contribution in the study of factors related to eye fatigue in employees of computer users at PT. Bank X Ambon City in 2018.

\section{METHOD}

The study design used was observational analytic with cross-sectional method. This research is located at PT. Bank X in Ambon City and held from March to April 2018. The population in this study was 25 employees of computer users of PT. Bank $\mathrm{X}$ in Ambon City. The sampling technique used is total sampling. The dependent variable in this study is eye fatigue while the independent variable in this study is the length of working time using a computer, the distance from the monitor and room lighting. Eye fatigue data were collected using a questionnaire according to the Ocular Surface Disease Index (OSDI) (Allergan, 2013). In addition, a roll meter is used to measure visibility, Lux meters measure lighting and observation sheets. The analysis used was univariate analysis and bivariate analysis. Bivariate analysis was carried out in this study to determine whether there was a relationship between the independent variables, namely the length of work, monitor distance and lighting with the dependent variable, namely eye fatigue, using the chi square formula with a significance test of $5 \%$. If $\mathrm{P}$ value $>0.05$, $\mathrm{Ho}$ is accepted and $\mathrm{Ha}$ is rejected, which means there is no relationship between the two variables. Conversation if $\mathrm{P}$ value $\leq 0.05$ then Ho is rejected and $\mathrm{Ha}$ is accepted, which means that there is a relationship between the two variables. If $\mathrm{P}$ value $<0.05$, the results show there is a relationship between the two variables.

\section{RESULTS AND DISCUSSION}

Eye Fatigue data were obtained by giving a questionnaire containing complaints of eye fatigue, according to Pheasant (Allergan, 2013) and to ensure that employees experiencing eye fatigue were used questionnaires based on the Ocular Surface Disease Index (OSDI). The highest distribution of respondents based on complaints of eye fatigue was found in the group that experienced eye fatigue and chose the "Yes" answer as many as 19 employees (76\%) while those who did not experience eye fatigue and chose "No" as many as 6 employees (24\%) (table 1) Then employees who experience eye fatigue complaints will be selected again based on the Ocular Surface Disease Index (OSDI) questionnaire to ensure employees who experience eye fatigue (Allergan, 2013).

Table 1.

Distribution of Respondents Based on Eye Fatigue Complaints on Employees at PT. Bank X Ambon City

\begin{tabular}{ccc}
\hline Undergo Complaints of Eye Fatigue & $\mathbf{N}$ & $\boldsymbol{\%}$ \\
\hline Yes & 19 & 76 \\
\hline No & 6 & 24 \\
\hline Total & $\mathbf{2 5}$ & $\mathbf{1 0 0}$ \\
\hline
\end{tabular}

Distribution of respondents based on eye fatigue on employees of computer users at
PT. Bank $X$ in Ambon City, in the category of tiredness or suffering from eye fatigue if 
the score $>10$ is 14 employees $(56 \%)$ while the lowest distribution of respondents is in the category of not tired or not suffering from eye fatigue if the score $<10$ is 11 employees $(44 \%)$ (table 2).

Table 2.

Distribution of Respondents Experiencing Eye Fatigue in Employees at PT. Bank X in Ambon City

\begin{tabular}{ccc}
\hline Eye Fatigue & $\mathbf{N}$ & $\mathbf{\%}$ \\
\hline Tired, if the score is $>10$ & 14 & 56 \\
\hline Not Tired, if the score is $<10$ & 11 & 44 \\
\hline Total & $\mathbf{2 5}$ & $\mathbf{1 0 0}$ \\
\hline
\end{tabular}

The results of the research conducted on computer user employees at PT. Ambon City Bank $X$ in 2018 proves that of the 25 employees studied, most experienced eye fatigue because of complaints of symptoms or complaints of eye fatigue. The number of employees who experienced eye fatigue complaints was as many as 19 employees (76\%) using questionnaires from Pheasant by checking the perceived symptoms while the positive ones suffering from eye fatigue from 19 employees were 14 employees (56\%). This amount was obtained from categories based on the total score filled by employees on the Ocular Surface Disease Index (OSDI) questionnaire and adjusted also to the Ocular Surface Disease Index (OSDI) graph.

For the relationship of working time using a computer with eye fatigue on employees of computer users at PT. Ambon City Bank X in 2018 , based on working time is divided into two categories, namely the category does not meet the standard ( $>2$ hours / day) and meets the standard ( $\leq 2$ hours / day). The category does not meet the standards is the category with the highest distribution of respondents as many as 19 employees $(76 \%)$ with the following details, namely employees who do not meet the standards if working $>2$ hours non-stop and suffer eye fatigue as many as 14 employees (100\%) while those that do not meet the standard and not suffer eye fatigue as many as 5 employees $(45.5 \%)$. Then the category with the lowest distribution of respondents is the standard-fulfilling category of 6 employees (24\%) with details as follows: there are no employees who meet the standard if working < 2 hours non-stop and suffering from eye fatigue $(0 \%)$ while those who meet the standards and do not suffer eye fatigue as many as 6 employees $(54.5 \%)$ (table 3). Chi square statistical test results are known as 5\% degrees obtained by value $=0.003$ or $(\mathrm{p}<0.05)$ then the null hypothesis (Ho) is rejected and the alternative hypothesis ( $\mathrm{Ha}$ ) are accepted so that it can be concluded that working time using computers with eyestrain has a meaningful relationship.

Table 3.

Duration of Work Using a Computer with Eye Fatigue in Employees of Computer Users.

\begin{tabular}{|c|c|c|c|c|c|c|c|}
\hline \multirow{3}{*}{ Working time duration } & \multicolumn{4}{|c|}{ Eye Fatigue } & \multirow{2}{*}{\multicolumn{2}{|c|}{ Score }} & \multirow{3}{*}{ p value } \\
\hline & \multicolumn{2}{|c|}{ Tired } & \multicolumn{2}{|c|}{ Not tired } & & & \\
\hline & $\mathbf{n}$ & $\%$ & $\mathbf{n}$ & $\%$ & $\mathbf{N}$ & $\%$ & \\
\hline Not fulfilling the standard, if $>2$ hours / day & 14 & 100 & 5 & 45.5 & 19 & 76 & \multirow{2}{*}{0.003} \\
\hline Fulfilling the standard, if $\leq 2$ hours / day & 0 & 0 & 6 & 54.5 & 6 & 24 & \\
\hline Total & 14 & 100 & 11 & 100 & 25 & 100 & \\
\hline
\end{tabular}


Based on the results of research, eye fatigue suffered by employees who worked $>2$ hours non-stop in a day, 14 employees. The employees complained about 7-9 symptoms in the Pheasant questionnaire and were shown to experience eye fatigue with the highest number of scores based on the number of Ocular Surface Disease Index (OSDI) and adjusted to the Ocular Surface Disease Index (OSDI) graph. In addition, some of the employees also use minus glasses after starting to work as employees of computer users at PT. Bank $\mathrm{X}$ in Ambon City.

The National Institute for Occupational Safety and Health (NIOSH) recommends using computers when working no more than two hours a day and CVS Statistics also recommend not using a computer when working more than two hours a day (Computer Vision Syndrome Statistic, 2017). This is in accordance with the results of a survey conducted by the National Institute for Occupational Safety and Health (NIOSH) which reported that $75-90 \%$ of computer users more than two hours a day had eye vision problems and had the same results as Suma'mur's theory of influence from poor lighting is eye fatigue with reduced power and work efficiency, mental fatigue, sore complaints in the eye area and headaches around the eyes, visual impairment and increased accidents (Suma'mur, 2013).

Research conducted by Rudhianti, et al (2015), shows that there is a relationship between the duration of playing video games and the visual acuity of school-age children
(Class III - V) in Majalaya Elementary School 2. Research Moon, et al (2014), also shows a relationship between duration of smartphone use at the risk of dry eye disease $(p=0.027)$. Some research results from previous studies such as those conducted by Fadhillah, (2013); Septiansyah, (2014); Sya'ban \& Riski, (2014) prove the cause of eye fatigue, namely long working hours using a computer in a day, the distance of the eye that is too close to the monitor, and the lighting conditions of the workspace.

This is also in line with the opinion expressed by the American Optometric Association (AOA) that the length of working time using a computer for more than 2 hours can cause eye fatigue, and if no preventive measures are taken, eye fatigue can also affect and worsen eye health. Because in addition to displaying images and text, computer monitors can also emit radiation and waves that cannot be detected by the eye such as ultraviolet (UV) and X-rays. According to John E. Coal, computer radiation, namely Xrays can cause physiological disturbances in the eye, if exposed for a long time. In addition, research carried out in America, the emission of electromagnetic waves caused by computer monitors can cause asthenopia and if not handled quickly it will end in damage to the retina, cataracts and even worse can cause blindness due to radiation from electromagnetic waves produced by monitor not ionized. This radioactive emission will continue to be active until it has run out in 20 years. Damage to the eye is not direct, but is gradual (Santoso, 2013).

Tabel Table 4.

Distance Monitor with Eye Fatigue in Employees of Computer Users at PT. Bank X in Ambon City

\begin{tabular}{|c|c|c|c|c|c|c|c|}
\hline \multirow{3}{*}{ Distance to the Monitor } & \multicolumn{4}{|c|}{ Eye Fatigue } & \multirow{2}{*}{\multicolumn{2}{|c|}{ Score }} & \multirow{3}{*}{ P value } \\
\hline & \multicolumn{2}{|c|}{ Tired } & \multicolumn{2}{|c|}{ Not tired } & & & \\
\hline & $\mathbf{n}$ & $\%$ & $\mathbf{n}$ & $\%$ & $\mathbf{N}$ & $\%$ & \\
\hline Not fulfilling the standard, if $<40 \mathrm{~cm}$ & 4 & 28.6 & 1 & 9.1 & 5 & 20 & \multirow{2}{*}{0.245} \\
\hline Fulfilling the standard, if $\geq 40 \mathrm{~cm}$ & 10 & 71.4 & 10 & 90.9 & 20 & 80 & \\
\hline Total & 14 & 100 & 11 & 100 & 25 & 100 & \\
\hline
\end{tabular}


According to the Occupational Safety and Health Administration (OSHA) it is stated that the eye distance to the monitor screen when working on a computer is at least 40-70 $\mathrm{cm}$ (Occupational Safety and Health Administration (OSHA), 2017). Relationship between monitor distance and eye fatigue in employees of computer users at PT. Ambon City Bank X in 2018, based on the distance of the monitor, is divided into two categories, namely the category does not meet the standard $(<40 \mathrm{~cm})$ and meets the standard $(\geq$ $40 \mathrm{~cm})$. The category meets the standard is the category with the highest distribution of respondents as many as 20 employees $(80 \%)$ with details as follows employees who meet the standards but suffer eye fatigue as many as 10 employees $(71.4 \%)$ while those who meet the standards and do not suffer eye fatigue as many as 10 employees $(90.9 \%$ ) Then the category with the lowest distribution of respondents is the category does not meet the standards as many as 5 employees (20\%) with details as follows employees who do not meet the standards and suffer eye fatigue as many as 4 employees $(28.6 \%)$ while those that do not meet the standards but do not suffer eye fatigue as much as 1 employees $(9.1 \%$ ) (table
4). The chi square statistical test results are known at $5 \%$ degrees obtained by Pvalue $=$ 0.245 or $(p>0.05)$ then the null hypothesis (Ho) is accepted and the alternative hypothesis (Ha) is rejected so it can be concluded that the distance of the monitor with eye fatigue does not have a meaningful relationship. This research is in line with Berliana \& Rahmayanti, (2017), which states that there is a relationship between monitor distance and eye fatigue ( $\mathrm{p}$ value 0.000). Ergonomic distance between non-ergonomic ones will risk causing eye fatigue.

When measuring distance monitor the condition of the table, chair and position of the computer is good and also gives an influence on the comfort of view when working. In the results of this study there were also 1 employee (9.1\%) who worked with a monitor that did not meet the standard but did not suffer from eye fatigue and there were 10 employees (90.0\%) who worked with a monitor that met the standard and did not experience eye fatigue. This can occur because of the long working time using a computer <2 hours / day and having room lighting or local lighting on a good work desk even though visibility does not meet the standards.

Table 5.

Room Lighting with Eye Fatigue at Employees at PT. Bank X in Ambon City

\begin{tabular}{|c|c|c|c|c|c|c|c|}
\hline \multirow{3}{*}{ Room Lighting } & \multicolumn{4}{|c|}{ Eye Fatigue } & \multirow{2}{*}{\multicolumn{2}{|c|}{ Total }} & \multirow{3}{*}{$p$ value } \\
\hline & \multicolumn{2}{|c|}{ Tired } & \multicolumn{2}{|c|}{ Not tired } & & & \\
\hline & n & $\%$ & $\mathbf{n}$ & $\%$ & $\mathbf{N}$ & $\%$ & \\
\hline Not fulfilling the standard, if < 300 lux & 3 & 21.4 & 7 & 63.6 & 10 & 40 & \multirow{2}{*}{0.042} \\
\hline Fulfilling the standard, if $\geq 300$ lux & 11 & 78.6 & 4 & 36.4 & 15 & 60 & \\
\hline Total & 14 & 100 & 11 & 100 & 25 & 100 & \\
\hline
\end{tabular}

The Occupational Safety and Health Administration (OSHA) explains that for work environments where many work use computers, if the lighting level or lighting intensity is too high it will obscure the image or display of the monitor screen, because the monitor also has or produces its own light that appears when operated. So that the work environment for workers with monitors, lighting levels or room lighting intensity must be set lower than the standard for office space, the appropriate lighting level or lighting intensity is the range of 300-500 lux. The intensity of lighting is also not required. Because it only applies to rooms where there are no table lamps used (Occupational Safety 
and Health Administration (OSHA), 2013). Relationship between room lighting and eye fatigue in computer user employees at PT. Ambon City Bank X in 2018, based on room lighting is divided into two categories, namely the category does not meet the standard (<300 lux) and meets the standard ( $\geq 300$ lux). The category meets the standard is the category with the highest distribution of respondents as many as 15 employees $(60 \%)$ with details as follows: employees who meet standards and suffer eye fatigue as many as 11 employees $(78.6 \%)$ while employees who meet the standards and do not suffer eye fatigue as many as 4 employees $(36.4 \%)$. Then the category with the lowest distribution of respondents is the non-standard category of 10 employees $(40 \%)$ with details as follows: employees who do not meet standards and suffer eye fatigue as many as 3 employees (21.4\%) while employees who do not meet the standards but do not suffer eye fatigue as much 7 employees (63.6\%) (table 5). Chi square statistical test results are known at 5\% degrees obtained by Pvalue $=0.042$ or $(\mathrm{p}$ $<0.05$ ) then the null hypothesis (Ho) is rejected and the alternative hypothesis $(\mathrm{Ha})$ is accepted so that it can be concluded that room lighting with the eye has a significant relationship.

Suma'mur stated that the influence of poor lighting is eye fatigue and if not handled properly, poor lighting can lead to reduced power and work efficiency, mental fatigue, sore complaints in the eye area and headaches around the eyes, damage to the visual instrument and can increase workplace accidents (Suma'mur, 2013). The lighting conditions of the workspace at PT. Bank X is very good because there are 15 measurement points that have good or standard lighting. Besides the lights in the room function properly and cleanly and some rooms use two lighting sources, namely natural and artificial lighting. The use of lighting sources is based on the weather. If the weather starts to light, the employee starts to close the window curtains and vice versa. While the lighting conditions are not good or do not meet the standards are less than not at risk because the location of a work desk away from the window or glass windows that are blocked by buildings and so on and work desks are located in the corners of the room that lack light reflection from the lights.

This is in line with the research (Wiyanti \& Martiana, 2015), showing that there is a relationship between the intensity of illumination and eye fatigue on batik artisans. The research conducted by Prayoga, Budiono, \& Widowati, (2014), shows that there is a relationship between the intensity of lighting and eye fatigue in medical personnel in the inpatient department of RSUD Dr. Soediran Mangun Sumarso Wonogiri.

Eye fatigue caused by lighting the room can be prevented by making arrangements such as natural and artificial lighting strived to not cause glare and have intensity in accordance with its designation, the placement of light bulbs can produce optimum radiation and light bulbs are often cleaned, light bulbs that start do not work with well replaced immediately. As for special lighting for the monitor screen, the computer places the monitor screen next to the light source, not just below the light source. Try to work the desk between the lights. If the lamp used is a fluorescent strip lighting, the side of the work table is placed parallel to the lamp. Try not to put a screen near the window, but if it is unavoidable, make sure the computer screen or computer user does not face the window (Ministry of Health, 2016).

\section{CONCLUSIONS AND SUGGESTIONS}

Based on the results of research conducted on computer user employees at PT. Bank $\mathrm{X}$ in Ambon City in 2018, it can be concluded that there is a relationship between the length of time working using a computer and eye fatigue on employees of computer users at PT. Bank X in Ambon City in 2018, with a value of $p$ value $=0.003$ or $(p<0.05)$ and Phi 
$=0.634$, there is no relationship between monitor distance and eye fatigue in employees of computer users at PT. Bank X in Ambon City in 2018, with a value of $p$ value $=0.245$ or $(\mathrm{p}>0.05)$ and there is a relationship between room lighting and eye fatigue in employees of computer users at PT. Bank X in Ambon City in 2018, with a value of $p$ value $=0.042$ or $(p<0.05)$

Suggestion For the Company to disseminate information to employees about resting their eyes when working with computers to avoid eye fatigue due to long working hours using a computer. Room lighting and the layout of lights, windows and work desks need to be considered so that lighting is not too glare, too dim or creates a shadow to avoid eye fatigue due to room lighting and is expected to create a safe and comfortable work environment for employees. The ingredients for computer users are expected to use the 20/20/20 method to rest their eyes. Method 20/20/20 which is every 20 minutes working with a computer, interspersed with 20 seconds of short breaks, by looking at other than a computer as far as 20 feet. And every 2 hours work should be interspersed with stretches for 10-15 minutes, employees can use antiradiation glasses. For the next researcher can make the height of the eye to the monitor, refractive abnormalities, age and size of the object as one of the independent variables.

\section{REFERENCES}

Allergan. (2013). London SECO/AOP 2013 Purslow. Retrieved from https://www.eiseverywhere.com/file_u ploads/28dfc1f8329d606fc0f06fed28e 0c62b_Handouts.pdf

Berliana, N., \& Rahmayanti, F. (2017). Faktor - Faktor yang Berhubugan dengan Keluhan Kelelahan Mata pada Pekerja Pengguna Komputer di Bank X Kota Bangko. Jurnal Kesehatan
Terpadu, 1(2), 68-72. Retrieved from https://jurnal.undhirabali.ac.id/index.p hp/kesehatan/article/view/270/248

Computer Vision Syndrome Statistic. (2017). Computer Vision Syndrome Statistic. Retrieved from http://endofcyberspace.com/2006/01/c yberspace_web_html

Fadhillah, S. L. (2013). Faktor-Faktor yang Berhubungan dengan Keluhan Kelelahan Mata pada Pengguna Komputer di Accounting Group PT Bank X, Jakarta Tahun 2013. Universitas Islam Negeri Syarif Hidayatullah Jakarta. Retrieved from http://repository.uinjkt.ac.id/dspace/bit stream/123456789/26520/1/SELISCA LUTHFIANA FADHILLAHFKIK.pdf

Ilyas, S., \& Yulianti, S. R. (2017). Ilmu Penyakit Mata (5th ed.). Jakarta: Fakultas Kedokteran Universitas Indonesia.

Ministry of Health. (2013). Riset Kesehatan Dasar. Jakarta. Retrieved from http://www.depkes.go.id/resources/do wnload/general/Hasil Riskesdas 2013.pdf

Ministry of Health. (2016). PMK RI No 48 Tahun 2016 tentang Standar Keselamatan dan Kesehatan Kerja Perkantoran (2016). Jakarta. Retrieved from

http://www.kesjaor.kemkes.go.id/docu ments/PMK_No. 48 ttg_Standar_Kes elamatan_dan_Kesehatan_Kerja_Perka ntoran_.pdf

Moon, J. H., Kim, K. W., \& Moon, N. J. (2014). Association Between Video Display Terminal Use and Dry Eye Disease in School Children. Journal of Pediatric Ophthalmology and Stabismus, 51(2), 87-92. https://doi.org/10.3928/01913913$\underline{\text { 20140128-01 }}$ 
Moon, J. H., Kim, K. W., \& Moon, N. J. (2016). Smartphone use is a risk factor for pediatric dry eye disease according to region and age: a case control study. BMC Ophthalmology, 16(188), 1-7. https://doi.org/10.1186/s12886016-0364-4

Occupational Safety and Health Administration (OSHA). (2013). Light Ergonomics- General. Retrieved from https://www.ccohs.ca/oshanswers/ergo nomics/office/eye discomfort.html

Occupational Safety and Health Administration (OSHA). (2017). Positioning The Monitor. Retrieved from

https://www.ccohs.ca/oshanswers/ergo nomics/office/monitor_positioning.htm 1

Portello, J., Rosenfield, M., \& Bababekova, Y. (2012). Computer Related Visual Symptoms in Office Workers. Ophthalmic and Physiological Optics, 32 , $375-82$.

https://doi.org/10.1111/j.14751313.2012.00925.x. Epub 2012 Jul 7

Prayoga, A. H., Budiono, I., \& Widowati, E. (2014). Hubungan Antara Intensitas Pencahayaan dan Kelainan Refraksi Mata dengan Kelelahan Mata pada Tenaga Para Medis di Bagian Rawat Inap RSUD dr. Soediran Mangun Sumarso Wonogiri. Unnes Journal of Public Health, 3(4), 81-87. https://doi.org/10.15294/ujph.v3i4.389 $\underline{5}$

Rudhianti, F., Apriany, D., \& Hardianti, N. (2015). Hubungan Durasi Bermain Video Game dengan Ketajaman Penglihatan Anak Usia Sekolah. Jurnal Skolastik Keperawatan., 1(2), 12-17. Retrieved from http://jurnal.unai.edu/index.php/jsk/arti cle/view/83

Santoso, I. (2013). Interaksi Manusia dan Komputer. Yogyakarta: Andi.
Septiansyah, R. (2014). Faktor - Faktor yang Berhubungan dengan Kelelahan Mata pada Pekerja Pengguna Komputer di PT. Duta Astakona Girinda Tahun 2014. Universitas Islam Negeri Syarif Hidayatullah Jakarta. Retrieved from http://repository.uinjkt.ac.id/dspace/bit stream/123456789/29591/1/RANDY SEPTIANSYAH-FKIK.pdf

Shayla Wilson. (2015). Eye Strain. Retrieved from

http://www.med.umich.edu/1libr/Opht halmology/comprehensive/EyeStrain.p df/

Sheppard, A. L., \& Wolffsohn, J. S. (2018). Digital eye strain: prevalence, measurement and amelioration. $B M C$ Open Ophthalmology. https://doi.org/10.1136/bmjophth2018-000146

Suma'mur. (2013). Hygiene Perusahaan dan Kesehatan Kerja. Jakarta: Sagung Seto.

Supriadi, F. (2012). Faktor - Faktor yang Berkaitan dengan Kelelahan Mata pada Karyawan Bagian Administrasi di PT Indonesia Power UBP Semarang. Jurnal Kesehatan Masyarakat, 1(2), 720-730. Retrieved from http://eprints.undip.ac.id/37944/1/4436 .pdf

Sya'ban, A. R., \& Riski, I. M. R. (2014). Faktor-Faktor yang Berhubungan dengan Gejala Kelelahan Mata (Asstenopia) pada Karyawan Pengguna Komputer PT.Grapari Telkomsel Kota Kendari. In Proseding Seminar Bisnis \& Teknologi (pp. 1516). Lembaga Pengembangan Pembelajaran, Penelitian \& Pengabdian Kepada Masyarakat. Retrieved from https://media.neliti.com/media/publicat ions/169901-ID-faktor-faktor-yangberhubungan-dengan-ge.pdf

Wiyanti, N., \& Martiana, T. (2015). Hubungan Intensitas Penerangan 
Jurnal Aisyah: J urnal Ilmu Kesehatan, 4(1), J uni 2019, - 44

Lorna Yulaina Rary, Gracia Victoria Souisa, Bellytra Talarima

dengan Kelelahan Mata pada Pengrajin

Batik Tulis. The Indonesian Journal of

Occupational Safety and Health, 4(2),
$144-154$.

https://doi.org/10.20473/ijosh.v4i2.201

5.144-154 